\title{
Divergent effect of glucagon antibodies on arginine and glucose-stimulated insulin secretion in the rat
}

\author{
K. Tan, G. Atabani and V. Marks \\ Division of Clinical Biochemistry, University of Surrey, Guildford, Surrey, UK
}

\begin{abstract}
Summary. The effects of glucose and arginine on insulin secretion in the presence of glucagon antibodies were investigated in rats in vivo. In contrast to controls, animals given glucagon antibodies showed an inhibition of arginine-stimulated $(p<$ 0.001 ), but not glucose-stimulated, insulin secretion. That these effects were not due to incomplete neutralisation of endogenous glucagon is evidenced by the presence of large antibody excess throughout the duration of the experiments. Both the glucagonotropic effect of arginine $(319 \pm 60 \mathrm{ng} / \mathrm{l}$, $p<0.01)$ and the insulinotropic effect of exogenous glucagon
\end{abstract}

$(8.3 \pm 0.8 \mu \mathrm{g} / 1, p<0.001)$ were demonstrable under our experimental conditions in the absence of exogenous glucagon antibodies. These observations suggest that different mechanisms are involved in the stimulation of insulin release by arginine and by glucose, and that glucagon may play an important physiological role in the mediation and regulation of insulin secretion by secretogogues, such as arginine.

Key words: Paracrine, insulin secretion, glucagon secretion, glucagon antibodies, arginine, glucose, rat.
It is now established that the pancreatic islet of Langerhans contain A, B, D and PP cells which secrete, respectively, glucagon, insulin, somatostatin and pancreatic polypeptide [1]. By virtue of their anatomical juxtaposition, the sharing of a common extra-cellular space, and the existence of both tight and gap junctions, it seemed reasonable to assume that some mechanism exists whereby the pancreatic hormones suppress or stimulate each other's secretion [2-5]. Our understanding of these paracrine interrelationships has derived largely from pharmacological experiments and there has been some controversy regarding their physiological significance.

Understanding of the A- and B-cell interactions has remained confused. Physiological doses of glucagon are known to be hyperglycaemic and insulinotropic. Although this insulinotropic effect of glucagon was demonstrated as long ago as 1965 [6], there is still no proof that it is physiologically important. Conversely, it has not been established whether stimulation of the $B$ cell can occur in an A-cell free environment, since no chemical agents have been found that are capable of selectively destroying A cells. Hence it has been virtually impossible to study B-cell function in isolation from A cells.

We have approached this problem using antibodies specific for pancreatic glucagon in an attempt to neutra- lise A-cell function and/or block its secretion. In an earlier study, we showed that glucagon antibodies administered intraperitoneally did not affect plasma glucose, insulin or somatostatin concentrations despite extensive endogenous glucagon neutralisation [7]. Using this model, insulin secretion in response to arginine and glucose were investigated under conditions of glucagon deficiency.

\section{Materials and methods}

\section{Glucagon antibodies}

A high titre $(1: 180,000$ final) $\mathrm{C}$-terminal reactive rabbit anti-glucagon serum was obtained from Guildhay Antisera, Guildford, UK. The binding characteristics and capacity of the antibody and its ability in vivo to cause extensive neutralisation of endogenous glucagon have been described earlier [7]. Further studies on the specificity of the antiserum, and in particular, the absence of insulin antibodies were performed by incubating the glucagon antiserum in the presence of ${ }^{125} \mathrm{I}$ insulin. An insulin antiserum (Guildhay Antisera, Guildford, UK) acted as control. The recovery of insulin in the presence of glucagon antibodies was studied by the addition of exogenous insulin to plasma samples containing antiglucagon immunoglobulin at 1:50 and 1:100 dilutions and assaying for insulin.

An immunoglobulin fraction of the pooled glucagon antiserum was prepared by ammonium sulphate precipitation and the immunoglobulin fraction reconstituted with saline $(0.154 \mathrm{M})$. An immunoglobulin fraction of normal rabbit serum was similarly prepared. 



Fig. 1. Effects of glucagon $(1.5 \mathrm{mg} / \mathrm{kg}$ bodyweight, $\bullet$ ) and saline $(O)$ on plasma insulin and glucose concentrations in rats. Both groups $(n=6)$ received normal rabbit immunoglobulins $(0.5 \mathrm{ml})$ before the administration of glucagon. Results are mean $\pm \operatorname{SEM}(n=6)(* *=p<$ 0.001 and $*=p<0.005$ compared with saline control group)


Fig. 2. Plasma insulin and glucose concentrations following administration of D-glucose ( $2 \mathrm{~g} / \mathrm{kg}$ bodyweight) in rats $(n=6)$ given normal rabbit immunoglobulins $(0.5 \mathrm{ml}, O)$ or anti-glucagon immunoglobulins $(0.5 \mathrm{ml}, \bullet)$. Results are mean $\pm \operatorname{SEM}(n=6)(*=p<0.01$; $* *=p<0.005 ; * * *=p<0.001$ compared with value at zero time within the same group). No significant differences were observed between the two groups

\section{Experimental protocols}

Glucagon (Eli-Lilly, Indianapolis, Indiana, USA, $1.5 \mathrm{mg} / \mathrm{kg}$ bodyweight in saline) was administered intraperitoneally to six conscious male Wistar rats $(150 \mathrm{~g})$ given normal rabbit immunoglobulins $(0.5 \mathrm{ml})$ by intraperitoneal injection $45 \mathrm{~min}$ earlier. Six control rats received normal rabbit immunoglobulins $(0.5 \mathrm{ml})$ and saline intraperitoneally. The plasma glucose and insulin responses were observed at different time intervals. In a second series of experiments antiglucagon immunoglobulins $(0.5 \mathrm{ml})$ were injected intraperitoneally into conscious fed rats. Control rats received $0.5 \mathrm{ml}$ of the normal rabbit serum immunoglobulin fraction. After $45 \mathrm{~min}$, D-glucose ( $2 \mathrm{~g} / \mathrm{kg}$ body weight) or L-arginine $(1.5 \mathrm{~g} / \mathrm{kg}$ body weight) was administered intraperitoneally. Blood samples were obtained from the tail vein and assayed for plasma insulin, glucagon, glucose and excess antibody binding.

\section{Chemical analyses}

Immunoreactive insulin and pancreatic glucagon were determined by radioimmunoassay as previously described [7]. Plasma glucose was measured using a glucose oxidase method in a Beckman glucose analyser (Beckman Instruments, Fullerton, CA, USA).

\section{Statistical analysis}

Statistical analysis was performed using a two-tailed Student's t-test for unpaired data. Results are compared with values at zero time of the same group using the paired t-test, unless otherwise indicated. Results are expressed as mean \pm SEM.

\section{Results}

\section{Glucagon (1.5mg/ $\mathrm{kg}$ bodyweight) stimulation}

The insulinotropic and hyperglycaemic effects of glucagon were confirmed under the experimental conditions described (Fig. 1). At $15 \mathrm{~min}$, plasma insulin (8.3 $\pm 0.8 \mu \mathrm{g} / 1, p<0.001)$ and plasma glucose $(8.7 \pm 0.3$ $\mathrm{mmol} / \mathrm{i}, p<0.001$ ) were significantly raised over basal levels.

\section{D-Glucose ( $2 \mathrm{~g} / \mathrm{kg}$ bodyweight) stimulation}

D-glucose administration resulted in significant increases in plasma insulin concentrations in both the control animals given normal rabbit immunoglobulins $(p<0.001)$ and the test animals given glucagon antibodies $(p<0.01)$ (Fig. 2). There were no significant differences between the two groups. Plasma glucose levels were significantly raised above basal levels in both groups (Fig. 2), whilst a fall in plasma glucagon concentration was observed at 15 and $30 \mathrm{~min}$ after glucose injection in the control animals ( $p<0.02$; Fig. 4).

\section{L-Arginine ( $1.5 \mathrm{~g} / \mathrm{kg}$ bodyweight) stimulation}

In control rats treated with normal rabbit immunoglobulins, arginine stimulated insulin secretion $(p<0.005$; Fig. 3). In contrast, the insulinotrophic effect of arginine was inhibited in animals given glucagon antibodies ( $p<0.001$ compared with controls). Plasma glucose levels rose significantly in the control animals $(p<0.01)$ and a small but insignificant rise was also observed in the test animals followed by a rapid return to basal levels by $30 \mathrm{~min}$ (Fig. 3). No significant differences in plasma glucose concentrations were found between the two groups at any time point. Plasma glucagon levels were significantly raised $15 \mathrm{~min}$ after arginine injection in the control animals ( $p<0.01$; Fig. 4$)$.

\section{Plasma antiglucagon concentrations after glucagon antiserum and glucose or arginine stimulation}

Plasma samples collected from test animals after glucose or arginine administration were serially diluted with freshly prepared ${ }^{125}$ I-glucagon and assessed for titre and percentage binding of unbound antibodies. The extent of antibody binding of glucagon by undiluted rat plasma was made by extrapolating the percent binding of the antibody to zero dilution [8]. Excess antibodies were detectable in both experimental, ie glucose and arginine, groups throughout the duration of the study (range $75-78 \%$ Bound/Total ${ }^{125} \mathrm{I}$-glucagon) in concentrations equivalent to approximately $40 \mathrm{nmol} / 1$ glucagon binding capacity (Fig. 5). 



Fig. 3. Effects of L-arginine (1.5g/ $\mathrm{kg}$ bodyweight) on plasma insulin and glucose concentrations in rats $(n=6)$ given normal rabbit immunoglobulins $(0.5 \mathrm{ml}, O)$ or anti-glucagon immunoglobulins $(0.5 \mathrm{ml}, \bullet)$. Plasma insulin concentrations in the test animals were significantly different from control group at $15(* *=p<0.001)$ and $30 \mathrm{~min}$ $(*=p<0.005)$. Plasma glucose concentration was significantly raised in the control group at $15 \mathrm{~min}(* *=p<0.02$ compared with value at zero time) but not in the test group. No significant differences were observed for plasma glucose concentrations between the two groups. Results are mean $\pm \operatorname{SEM}(n=6)$

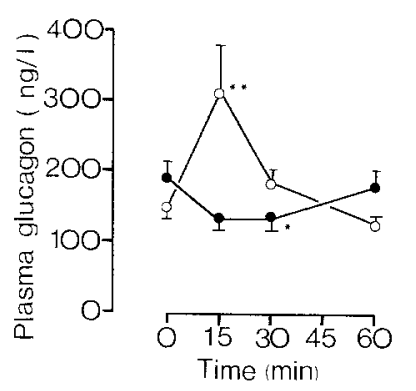

Fig. 4. Effects of D-glucose $(2 \mathrm{~g} / \mathrm{kg}, \bullet)$ and L-arginine $(1.5 \mathrm{~g} / \mathrm{kg}, \mathrm{O})$ on plasma glucagon concentration. Both groups received normal rabbit immunoglobulins. Results are mean $\pm \operatorname{SEM}(n=6)(*=p<0.02$; $* *=p<0.01$ )



Fig.5. Plasma antiglucagon levels as determined by percentage binding of ${ }^{125} \mathrm{I}$-glucagon following D-glucose $(2 \mathrm{~g} / \mathrm{kg}, \bullet)$ and L-arginine $(1.5 \mathrm{~g} / \mathrm{kg}, 0)$ stimulation. Results are mean $\pm \operatorname{SEM}(n=6)$

\section{Discussion}

In this study, a pool of antiglucagon antiserum raised in rabbits was used. Its binding capacity, avidity and titre were more potent than antisera used in previous studies [9-12]. Evidence for the specificity of the glucagon antibodies are described.

A major obstacle to elucidating the physiological role of glucagon has been the absence of any method that can selectively block A-cell function and/or secretion. In recent years, however, glucagon specific antibodies have been used for this purpose and have proved to be a powerful tool in unravelling glucagon's physiology by neutralising the effects of endogenous glucagon [12]. Using this approach, we have been able to demonstrate the inhibition of arginine-stimulated insulin release by glucagon antibodies. Administration of glucagon antibodies in vivo abolished the insulin response after arginine stimulation in rats. In addition, the glucagonotropic effect of arginine and the insulinotropic action of glucagon in the rat were also confirmed. These observations are consistent with the hypothesis that arginine and other amino acids that stimulate both glucagon and insulin secretion do so in a step-wise manner with glucagon serving as a mediator or potentiator of the insulinotropic effect [5]. Antibodies entering the islets may neutralise the A-cell glucagon and prevent its stimulation of the B cell.

In contrast to arginine, the glucose-stimulated insulin secretion was not impaired by glucagon antiserum. This divergence suggests that different mechanisms are involved in insulin release by parenteral glucose and arginine. Failure of the antibody to modify glucose-stimulated insulin secretion cannot, however, be attributed to incomplete neutralisation of endogenous glucagon as evidenced by the presence of excess antibodies at all time points in concentrations equivalent to approximately $40 \mathrm{nmol} / 1$ glucagon binding capacity. This ist excess of 1000 times the concentration of basal plasma glucagon levels of around 30pmol/1 [7].

There is general agreement that glucose has a direct effect on the B cell [13] either through being metabolised and forming specific metabolites or co-factors which initiate insulin release [14] or by activating glucoreceptors in the B-cell membrane [15]. Glucagon antiserum would not be expected to have any effect on such a direct B-cell action. In contrast, evidence from the present study suggests that the insulinotropic effect of arginine is glucagon dependent.

In an earlier study using a single pass perfusion system in the isolated rat pancreas, glucagon antibodies failed to affect somatostatin and insulin secretion following arginine stimulation [16]. Although the insulin response to arginine with glucagon antiserum tended to be lower than with non-immune serum, it was not found to be statistically significant. However, as conceded by the authors, since their experimental system is a single pass perfusion, access of the antibodies to the paracrine space may be difficult leading to incomplete neutralisation of glucagon. Our results are however consistent with those obtained by Tsiolakis [17] and Nishino et al. [18] who demonstrated inhibition of arginine-stimulated insulin secretion following intravenous glucagon antibody administration.

In their elegant studies using purified single A, B and $D$ cells from rat islets, Pipeleers et al. $[19,20]$ reported that single $B$ cells responded 2-4 fold more effective- 
ly to glucose when they were perfused together with A cells or incubated with exogenous glucagon. This effect was not associated with an increase in cell coupling but was attributed to the paracrine action of glucagon. It would appear that an optimal glucagon concentration in the vicinity of the B cell is necessary for insulin secretion. These studies provide direct evidence that the A cells play an important role in the regulation of insulin secretion from the B cells through a paracrine interaction. The evidence summarised here is consistent with this view, that endogenous glucagon is insulinotropic and plays an essential intermediary role in the stimulation of insulin secretion by certain secretogogues such as arginine.

Acknowledgements. This work was supported by a grant from the Medical Research Council, UK. The authors wish to thank Mrs J.McCall for her invaluable assistance in the preparation of the manuscript.

\section{References}

1. Orci L (1982) Macro and micro-domains in the endocrine pancreas. Diabetes 31:538-568

2. Marks V, Samols E (1968) Glucagon mediated insulin release. Acta Diab Latina 1968: (Suppl 1): 285-308

3. Marks V, Samols E (1968) Glucose homeostasis. In: James VHT (ed) Recent advances in endocrinology. Churchill Livingstone, London $\mathrm{p}$ 111-138

4. Marks V (1971) The biological significance of the insulinotropic effect of glucagon in man. In: Austoni M, Sandellari C, Federspil G, Trissotto A (eds) Current topics in glucagon. Cedam, Padova, pp 63-71

5. Samols E, Tyler J, Marks V (1972) Glucagon-insulin interrelationships. In: Lefebvre PJ, Unger RH (eds) Pergamon, Oxford, pp 151-173

6. Samols E, Marri G, Marks V (1965) Promotion of insulin secretion by glucagon. Lancet $2: 415-416$

7. Tan K, Tsiolakis D, Marks V (1985) Effect of glucagon antibodies on plasma glucose, insulin and somatostatin in the fasting and fed rat. Diabetologia 28: 435-440

8. Ebert R, Illmer K, Creutzfeldt W (1979) Release of gastric inhibitory polypeptide (GIP) by intraduodenal acidification in rats and humans and abolishment of the incretin effect of acid by GIP-antiserum in rats. Gastroenterology $76: 515-523$
9. Grey N, McGuigan JE, Kipnis DM (1970) Neutralization of endogeneous glucagon by high titre glucagon antiserum. Endocrinology $86: 1383-1388$

10. Barlin P, Beloff-Chain H (1973) Studies on the administration of glucagon and insulin antibodies to rats. Horm Metab Res 5: 154-159

11. Dunbar JC, Walsh MF, Foa PP (1978) The serum glucose response to glucagon suppression with somatostatin, insulin or antiglucagon serum in depancreatized rats. Diabetologia 14: 53-58

12. Holst JJ, Galbo H, Richter EA (1978) Neutralization of glucagon by antiserum as a tool in glucagon physiology. Lack of depression of basal glucose after antiserum treatment in rats. J Clin Invest 62: 182-190

13. Lacy PE (1977) The physiology of insulin release. In: Volk BW, Wellman KF (eds) Plenum Press New York, London pp 211-230

14. Grodsky GM, Batts AA, Bennett LL, Veella C, McWilliams NB, Smith DF (1963) Effects of carbohydrates on secretion of insulin from isolated rat pancreas. Am J Physiol 205: 638-644

15. Matschinsky FM, Ellerman JE, Krzanowski J, Kotler-Brajtburg J, Landgraf R, Fertel R (1971) The dual function of glucose in islets of Langerhans. J Biol Chem 246: 1007-1011

16. Seino S, Sakurai H, Kuzuya H, Tsuda K, Tanigawa K, Takahashi $\mathrm{K}$, Seino Y, Imura H (1982) Effect of glucagon antiserum on somatostatin, glucagon and insulin release from the isolated perfused rat pancreas. Peptides 1: 175-182

17. Tsiolakis D (1979) Regulation of insulin secretion by glucagon. PhD Thesis. Department of Biochemistry, University of Surrey, UK

18. Nishino T, Shima $\mathrm{K}$, Shimomura $Y$, Tanaka $R$, Kodaiva $T$, Imagawa K, Kumahara Y (1980) A study of the physiological role of glucagon. Passive immunization with antiserum specific for pancreatic glucagon in rats. Endocrinol Japn 1:109-113

19. Pipeleers DG, Pipeleers-Marichal MA (1981) A method for the purification of single $A, B$ and $C$ cells and the isolation of coupled cells from isolated rat islets. Diabetologia 20: 654-663

20. Pipeleers DG, In't Veld P, Maes E, Van de Winkel M (1982) Glucose-induced insulin release depends on functional co-operation between islet cells. Proc Natl Acad Sci 79: 7322-7325

21. Unger RH, Orci L (1981) Glucagon and the A-cell-physiology and patho-physiology. New Engl J Med 304: 1518-1524 (Part 1), 304: 1575-1580 (Part 2)

Received: 5 September 1984

and in revised form: 5 June 1985

Dr. Kim Tan/Professor Vincent Marks

Division of Clinical Biochemistry

University of Surrey

Guildford

Surrey 